\title{
Republic of Belarus: Report on Observance of Standards and Codes- Fiscal Transparency Module
}

This Report on the Observance of Standards and Codes on Fiscal Transparency for the

Republic of Belarus was prepared by a staff team of the International Monetary Fund as background documentation for the periodic consultation with the member country. It is based on the information available at the time it was completed on November 4, 2004. The views expressed in this document are those of the staff team and do not necessarily reflect the views of the government of the Republic of Belarus or the Executive Board of the IMF.

The policy of publication of staff reports and other documents by the IMF allows for the deletion of market-sensitive information.

To assist the IMF in evaluating the publication policy, reader comments are invited and may be sent by e-mail to publicationpolicy@imf.org.

Copies of this report are available to the public from

International Monetary Fund $\bullet$ Publication Services

700 19th Street, N.W. • Washington, D.C. 20431

Telephone: (202) 6237430 • Telefax: (202) 6237201

E-mail: publications@imf.org • Internet: http://www.imf.org

Price: $\$ 15.00$ a copy

\section{International Monetary Fund Washington, D.C.}





\title{
INTERNATIONAL MONETARY FUND
}

\section{REPUBLIC OF BELARUS \\ Report on the Observance of Standards and Codes (ROSC) Fiscal Transparency Module}

\author{
Prepared by the Fiscal Affairs Department \\ Approved by Michael Deppler and Teresa Ter-Minassian
}

November 4, 2004

\section{EXECUTIVE SUMMARY}

This report provides an assessment of fiscal transparency practices in Belarus in relation to the requirements of the IMF Code of Good Practices on Fiscal Transparency based on discussions with the authorities and other organizations, the authorities' response to the IMF fiscal transparency questionnaire, and other sources of information. The IMF Manual on Fiscal Transparency

(http://www.imf.org/external/np/fad/trans/manual/) should be consulted for further explanation of the terms and concepts discussed in this report. The assessment is based on the institutional and legal framework at the time of the IMF mission (April 21-30, 2003). ${ }^{1}$

Belarus meets the requirements of the fiscal transparency code in some important areas. There is a comprehensive legal and administrative framework for management of budget resources. The Budget systems law contains an explicit commitment to an open and transparent budget process, and budget coverage improved considerably with the inclusion of five major extrabudgetary funds into the budget in 1998. Budget execution mechanisms are quite effective, and budget execution reports are of consistent quality. The authorities are planning a number of important reforms to further improve fiscal management.

There are several areas where current practices fall short of the fiscal transparency code and improvements are required. In many of these areas, significant improvements could be realized quickly. There is little reporting on the public enterprise sector. Quasi-fiscal activities are widespread. The government produces considerable amounts of fiscal data and analysis, and more of this information could be made publicly available in a systematic way. Budget estimates are not based on a realistic medium-term macroeconomic framework, and do not reflect important fiscal risks. The budget fails to fully disclose the activities of government agencies, and the fiscal relationships between the central and local government are not fully defined. The Treasury does not yet cover the power ministries. The mechanisms for external assurances of the integrity of the fiscal processes need significant strengthening.

\footnotetext{
${ }^{1}$ The report does make reference to some plans and actions by the authorities following the IMF mission, but the staff was not in a position to assess the outcome and implications of these measures.
} 


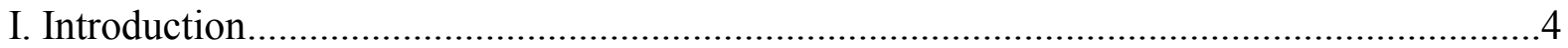

II. Description of Practice $\quad 4$

A. Clarity of Roles and Responsibilities ...............................................................4

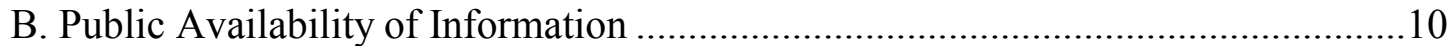

C. Open Budget Preparation, Execution, and Reporting ...........................................12

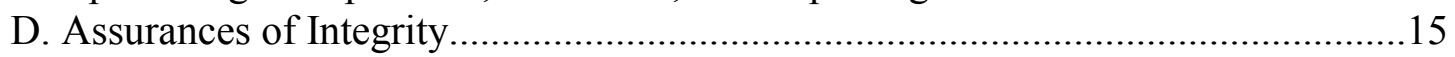

$\begin{array}{ll}\text { III. IMF Staff Commentary } & 17\end{array}$ 


\section{Abbreviations, ACronyms, AND Websites}

\begin{tabular}{|l|l|l|}
\hline BSL & Budget Systems Law & \\
\hline COM & Council of Ministers & \\
\hline GFS & Government Finance Statistics & \\
\hline IF & Innovation Funds & $\underline{\text { http://www2.main.gov.by/ }}$ \\
\hline MOE & Ministry of Economy & $\underline{\text { http://ncpi.gov.by/minfin/ }}$ \\
\hline MOF & Ministry of Finance & \\
\hline MOS & Ministry of Statistics & \\
\hline MTL & Ministry of Taxes and Levies & $\underline{\text { http://www.nbrb.by/engl/ }}$ \\
\hline NBB & National Bank of Belarus & \\
\hline NROLA & $\begin{array}{l}\text { National Register of Legal Acts of } \\
\text { the Republic of Belarus }\end{array}$ & http://www.president.gov.by/eng/ \\
\hline $\begin{array}{l}\text { Presidential } \\
\text { website }\end{array}$ & $\begin{array}{l}\text { Reports on the Observance of } \\
\text { Standards and Codes }\end{array}$ & \\
\hline ROSC & State Control Committee & \\
\hline SCC & $\begin{array}{l}\text { Special Data Dissemination } \\
\text { Standard }\end{array}$ & \\
\hline SDDS & System of National Accounts & \\
\hline SNA & Social Protection Fund & \\
\hline SPF &
\end{tabular}

\section{Belarus: Basic Data}

Type of government: Unitary Presidential Republic with bi-cameral Parliament

Fiscal year: Calendar

Population (December 2002): 9.9 million

GDP (2002): Rbl 25,5 trillion ( $\$ 14,3$ billion)

Debt/GDP (2002): 11 percent 


\section{INTRODUCTION ${ }^{2}$}

1. This draft report provides an assessment of fiscal transparency practices in Belarus against the requirements of the IMF Code of Good Practices on Fiscal Transparency. The assessment has two parts. The first part is a description of practice, prepared by the IMF staff on the basis of discussions with the authorities and their responses to the fiscal transparency questionnaire, and drawing on other available information. The second part is an IMF staff commentary on fiscal transparency in Belarus.

\section{Description of Practice}

\section{A. Clarity of Roles and Responsibilities}

\section{General government is fairly clearly defined, but some aspects require further} clarification. The general government encompasses the Republican (central) government, local governments (at the regional, district, and town and rural levels), the Social Protection Fund (SPF), a large number of Innovation Funds (IFs) and a few other extrabudgetary funds, that are subordinated to government ministries, agencies, and organizations. The accounts of the extrabudgetary funds are not consolidated with the consolidated accounts of the Republican and local governments. ${ }^{34}$ Many government ministries, committees, and agencies are explicitly allowed in the annual budget law not to include some of their revenues in the budget. ${ }^{5}$ However, in accordance with the budget law, the ministry of finance (MOF) monitors cash flows in the innovation funds, the Social Protection Fund, and budgetary organizations receiving income from commercial activity. The government is considering

\footnotetext{
${ }^{2}$ Discussions on fiscal transparency were held in Minsk during April 21-30, 2003. The staff team comprised Messrs. Eivind Tandberg (Head) and Dimitar Radev (both FAD), and Roman Zytek (EU). The mission met with officials from the ministry of finance (MOF), ministry of economy (MOE), ministry of statistics (MOS), and ministry of agriculture, the National Bank of Belarus (NBB), representatives of both houses of Parliament, the State Control Committee (SCC), the Social Protection Fund, the Minsk City Council, Magilevskaya Oblast, Shklow, Belarusbank, and the Institute of Economy, as well as representatives of civil society.

${ }^{3}$ Examples of other extrabudgetary funds are the Fund for the Development of Construction Science or the Stabilization Fund of the ministry of posts and telecommunications.

${ }^{4}$ General government consists of the following entities: the presidency, parliament, cabinet of ministers, 24 ministries, a number of state committees and agencies, six regional (oblast) and Minsk city governments, 118 districts (rayons) and 110 rayon-level cities and towns and 25 district cities and towns, 103 semi-urban centers, 1,455 rural councils, and 24,117 rural settlements, and the SPF. The Belarusian Parliament (called the National Assembly) comprises two houses - the House of Representatives (lower house with 110 Deputies) and the Council of the Republic (the upper house with 64 Deputies).

${ }^{5}$ Paragraph 35 of the Law on the 2003 Budget provides a detailed list of ministries, committees, and organizations that do not include in the republican budget revenues from various activities, such as sale of assets, including real estate, and provision of paid services.
} 
expanding the coverage of the state budget to include some of those cash flows in the 2004 Budget Law. ${ }^{6}$

\section{Government activities are not clearly distinguished from those of public} financial institutions and nonfinancial public enterprises. Although a large number of public enterprises have been transformed from state enterprises into clearly defined and distinguished state-owned corporations, their activities continue to be closely related to the government. The state enterprise sector receives numerous types of budgetary and extrabudgetary support. At the same time, enterprises (including even in the private sector) are expected, and often required to engage in uncompensated quasi-fiscal activities in support of various government programs and objectives. Therefore, although nominally the autonomy of the unitary state-owned corporations is clearly defined, the entire public sector is subject to heavy influence from the government.

\section{The privatization processes has been very gradual and its transparency has}

room for improvement. Following the government's privatization program, the government prepares annually lists of republican-level enterprises that are to be corporatized and privatized during the following year. ${ }^{7}$ Similarly, local governments are responsible for selecting municipally-owned entities that are to be privatized. Belarus has made only limited progress in privatizing its public enterprises and there is no complete, publicly available list of privatized enterprises. ${ }^{8}$ A voucher privatization scheme has brought disappointing results, partly because it excluded more attractive and profitable enterprises. ${ }^{9}$ As required by law, the government disseminates information on the privatization schedule in periodicals. The recently announced privatization offering for 2003, although relatively transparent, imposed many highly restrictive conditions on potential buyers and, at least so far, has attracted only limited interest. Information about privatization receipts has been clearly disseminated to the public and is recorded in the budget execution reports as capital revenue. So far, the authorities have not made any decision on the use of the Slavneft proceeds.

\footnotetext{
${ }^{6}$ The SPF is included in the general government budget in 2004.

${ }^{7}$ Concept Paper on the Management of the State Property in the Republic of Belarus for 2001-05 adopted by the government (Decree of the Council of Ministers (COM) No 1240 of August 10, 2000 ).

${ }^{8}$ In the Belarus statistical system, wholly-owned government enterprises are classified as private sector following corporatization.

${ }^{9} 47$ percent of the privatization vouchers issued during April 1, 1994-January 1, 1997 have not been redeemed for shares so far, despite the fact that the vouchers expired on June 30, 2003.
} 
5. The central bank is independent within the limits set in the Banking Code, ${ }^{10}$ and plays a significant fiscal role. The Banking Code grants the central bank only limited independence, as it is answerable to the President and does not explicitly bar the NBB from financing government deficits. Its main objectives are defined as: (i) defending the stability of the ruble; (ii) development and strengthening of the banking system; and (iii) supervision over the payment system. Profit maximization is explicitly ruled out as an objective of central banking operations. The NBB has played a significant quasi-fiscal role. Its loans to the government carry only a very small interest cost and it has routinely engaged in lending to the commercial banks. ${ }^{11}$ Its ability to carry out monetary policy has been severely restricted by low holdings of international reserves and the non-transferable character of the NBB's claims on the government. ${ }^{12}$

\section{Government regulation of the nonbank private sector is not implemented with} clear simple regulations and open regulatory process. Private sector remains very small in Belarus. Private companies face numerous bureaucratic procedures and frequently changing regulations including tax rules. Many activities require special licenses and permits, and businesses are subjected to frequent intrusive controls from various government agencies. Although direct price controls are being gradually eliminated, they are often replaced with more subtle, indirect measures to control prices and profits. ${ }^{13}$ Private companies have to follow detailed wage regulations that include a salary scale prescribing minimum wages depending on employees' profession, education attainment, job experience and rank. ${ }^{14}$

7. Government equity holdings are extensive, but are not yet clearly reported. The MOE is responsible for maintaining registrar of republican-level property holdings. Municipal property holdings are registered and managed by local government property funds. Consolidated reports on state share holdings in enterprises are reflected in the registry of state property. Lists of government equity holdings are also maintained by the sector ministries supervising state companies and unitary state-owned corporations, the MOE, the ministry of

\footnotetext{
${ }^{10}$ The activities of the NBB are regulated by the Banking Code of October 25, 2000. In particular, Chapter I para. 7 defines the role and functions of the central bank, and Chapter II (National Bank) contains detailed regulations for central bank activity.

${ }^{11}$ As part of Belarusian commitments foreseen in the agreements on the monetary union with Russia, the government has been preparing amendments to the Banking Code that, when implemented, will increase the independence of the NBB and the banking sector from government intervention. The amendment will also explicitly prohibit central bank direct lending to the government, including the purchase of government securities in the primary market.

12 The 2004 Budget Law stipulates securitization of NBB's holdings of loans to the government.

${ }^{13}$ For example, Minsk restaurants have to comply with regulations setting explicit limits on profit margins.

14 The pay scale was introduced as a measure to strengthen tax compliance by reducing opportunities and incentives for underreporting labor compensation to lower social security liabilities.
} 
taxes and revenues (MTL), and the MOS. These ministries also collect detailed information on the economic activities of public enterprises, but do not disseminate detailed information to the public on a regular basis. ${ }^{15}$ The MOS disseminates highly aggregated data on some key flows and balance sheet items (such as receipts, profits, share of barter in total transactions volume, as well as information on the domestic and foreign accounts receivables and payables, including arrears) in its monthly statistical publications. Officials in the MOE have argued that more disaggregate and detailed technical and financial data can be released upon request, but that the interest among the general public for such detailed information had been too limited to justify regular reporting. However, some data are considered confidential and cannot be released even upon request.

\section{The allocation of revenue between different levels of government is relatively} clearly defined in the annual budget law and intergovernmental fiscal relations have tended to be quite stable. The allocation of revenues between the central and local governments is determined in the annual budget law, and the allocation coefficients for various taxes vary by region but tend to remain stable over time. The determination of the tax-sharing coefficients is the result of past experience, annual negotiations, and an explicit attempt to ensure adequate funding given the expected levels of economic activity and tax receipts in the region. Central government transfers to the regions include earmarked appropriations (subsidies and subventions), transfers from the Fund for Financial Support of Regions to finance protected areas of expenditure and loans with maturity within the year to cover short-term cash shortfalls. Local budget expenditure obligations are less explicitly defined. The Budget System Law (BSL) stipulates that local governments secure the financing of economic, social, cultural, and other endeavors undertaken on the respective territory, without providing any specific detail on the actual activities to be financed at the local level. ${ }^{16}$ In practice, the allocation of expenditure between different levels of government is a function of established practices, more than specific legislation.

\section{According to the legislation of the Republic of Belarus, the Institute of the} President plays a significant role in regulating the fiscal sphere. The president has wide rights of legislative initiative. The president issues decrees, edicts and resolutions which can amend the revenue and expenditure parts of the budget. ${ }^{17}$ Decrees have the force of laws. ${ }^{18}$ Presidential decrees and edicts are superior to the legislative acts issued by the other state bodies and state officials. However, the president is not empowered to approve the republican budget and reports on its execution, as these rights belong to the exclusive competence of the

\footnotetext{
${ }^{15}$ Summary information on the developments in the privatization area as well as some data on state shareholdings in Belarus corporations are published on the MOE's website www2.main.gov.by.

${ }^{16}$ Law on Budget System and State ExtrabudgetaryFunds of June 4, 1993.

${ }^{17}$ Law on Budget System and State ExtrabudgetaryFunds of June 4, 1993.

${ }^{18}$ Constitution of the Republic of Belarus.
} 
parliament. ${ }^{19}$ The government regularly reports on execution of the budget to the parliament and to the president.

\section{Fiscal management is covered by a reasonably clear legal and administrative} framework, but it is not fully comprehensive. The BSL and the annual republican budget law and local government budget resolutions are the main legislative instruments for state and local government financial management, while the Law on Budget Classification provides instructions on the classification of revenues and expenditure for all budgetary organizations. The BSL regulates the composition, preparation and implementation of the annual budgets. However, provisions in the BSL can be corrected by sectoral codes, the annual budget law and presidential decrees. The government has now started drafting a budget code to systematize all budget legislation in a single document, strengthen budget management, and ensure that the integrity of fiscal management is not undermined by other legislation.

\section{Mechanisms for the coordination and management of budgeted and} extrabudgetary activities are relatively well defined. Extrabudgetary activities are carried out by the SPF (with revenues and expenditure of about 12 percent of GDP) and a large number of relatively small Innovation Funds (with receipts and expenditure accounting for about 2 percent of GDP). The operations of the SPF are governed by the law on the basis for the state social insurance, while the innovation funds are governed by government decisions. ${ }^{20}$ SPF activities are relatively transparent, as both SPF's annual budgets and execution reports are reported to and approved by the parliament. The bulk of SPF's revenues come from social protection contributions that are based on well publicized and relatively transparent rules. The SPF accounts are compiled quarterly. ${ }^{21}$ In the past, the SPF's financial resources have been routinely used to purchase government securities. The activities of the innovation funds are less transparent and, according to legislation, the information on their activities is not required to be either regularly reported to the parliament or disseminated to the public. The annual law on budget allows ministries and government agencies to establish innovation funds to support a vast list of objectives, ranging from research and development to "other." They are financed from innovation fund contributions collected from enterprises under the ministry or organization that established the fund, outside the treasury system. ${ }^{22}$

\footnotetext{
${ }^{19}$ Constitution and Law on the President of the Republic of Belarus.

${ }^{20}$ Decree of the COM No. 1346 on the Procedure for Generation and Disbursement of the Proceeds of the Innovation Funds, September 30,2002; http://mail.ncpi.gov.by:8081/webnpa/text.asp?RN=C20201346.

${ }^{21}$ In 2004 the SPF is included in the general government budget.

22 The Law on the 2004 Budget stipulates the innovation funds rate of 0.25 of total costs. The government has the right to set higher rates for different ministries (up to 20 percent). In addition, the draft 2005 budget stipulates that innovation funds will be included in the general government budget and their transactions will be performed via the state treasury system in accordance with budget legislation of the Republic of Belarus.
} 


\section{Mechanisms for the coordination of the budget, the central bank and the} commercial banks could be more stringently defined and implemented. In the past few years, the central bank and commercial banks have provided the bulk of general government financing and the government has routinely guaranteed commercial bank credits to the public enterprise sector. The annual budget laws specify central bank profit and direct financing to the budget, and planned financing through treasury bills and notes (GKOs and GDOs). The limit for state securities placement as a financing item is set in the law on budget for the current fiscal year. Expenditures related to issuing and servicing the securities are planned based on the inflation forecast and other parameters set in the main monetary policy framework adopted by the NBB. The MOF can place its debt through a number of channels. Treasury securities can be sold through auctions carried out at the Belarus Currency and Stock Exchange, placed directly with investors on mutually agreed terms, sold to or through banks (through bank underwriting). Direct private placements of state securities are undertaken in order to raise funds quickly when an auction is not possible owing to lack of at least two participants, as required by the civil code. During 2001 and 2002 (in particular during January-June) the government, when facing severe financial crunch and unable to sale more than just a fraction of its T-bill offering, resorted to directly placing its debt with investors to raise funds. The republican government has also placed securities, often denominated in foreign currencies, to cover its guarantees to banks on nonperforming loans. In late 2002, local governments turned to borrowing from commercial banks (outside the treasury system) for more than just very short-term loans.

\section{Legislative basis for taxation, regulation and administrative procedures are clear} but are not necessarily observed in practice. Taxes, customs duties and other duties are regulated by The Law on Taxes and Revenues as well as laws on individual taxes. ${ }^{23}$ However, until recently, many economic units enjoyed a large number of discretionary exemptions, and the information on the exemptions has not been transparent. ${ }^{24}$ The authorities have been preparing a new tax code. ${ }^{25}$

14. Public servants are subject to a code of behavior. The behavior of public servants is regulated by the Law on the Fundamentals of Service in Government Administration of November 23, 1993 and the anti-corruption law. ${ }^{26}$ Upon employment, public servants are expected to sign their pledge to abide by these laws and are also required to report their

\footnotetext{
${ }^{23}$ Law on Taxes and Revenues collected by the Budget of the Republic of Belarus, December 20, 1991.

${ }^{24}$ Decree No. 11 of the President of the Republic of Belarus of April 19, 2002 prohibited extending tax and customs exemptions and discounts to legal entities and individual entrepreneurs starting January 1, 2003.

${ }^{25}$ The General Part of the Tax Code became effective starting 2004, except for some stipulations that will be enforced together with the special part of the tax code, that is under development.

${ }^{26}$ Decree of the President of the Republic of Belarus No. 29 of July 26, 1999 on Additional Measures to Improve Labor Relations and Strengthen Labor and Performance Discipline.
} 
income. The law seems to be observed in practice albeit it is difficult to verify actual law enforcement with respect to high level public servants.

\section{B. Public Availability of Information}

15. The budget documents cover most central government fiscal activities but do not provide comprehensive and detailed information on general government fiscal activity. The annual budget document is focused on the Republican budget but MOF disseminates information on the consolidated budget. ${ }^{27}$ The budget and the summarized budget execution data are published at http://ncpi.gov.by/minfin/ and on http://www.president.gov.by/Minstat/main.html.

16. Defense expenditures are reported in the budget. The annual budget document contains an explicit line showing expenditure on national defense, as well as the allocation of this appropriation between different ministries. The data on defense spending are shown at a more aggregate level than expenditure of other sectors. Some dual use, defense-related expenditure is likely classified under different budget categories.

17. Annual budget laws present only the information on the current fiscal year. The budget document does not contain the main fiscal aggregates for past years nor the projections for the years beyond the current budget year.

18. Statements on some contingent liabilities are included in the budget document presented to parliament but little information on contingent liabilities is publicly disclosed. Annual budget documents include expenditure on projected contingent liabilities that will turn into actual liabilities during the budget year. The MOF has a solid information base on the outstanding contingent liabilities that arise from the issue of guarantees on foreign financed loans to Belarusian enterprises. Since 2001, the MOF also maintains a register of government guarantees on domestic bank loans to residents. There are no estimates for other types of liabilities, such as on the potential costs of recapitalizing banks or future liabilities of the pension system. Indeed, the SPF is planning to establish an actuarial service to begin work on making longer-term projections of the sustainability of the pension system.

19. No estimates of tax expenditures are contained in the budget, and no such estimates are presented to parliament separately or made available to the public. Although a number of tax concessions are granted openly and are somewhat transparent, a number of different, less transparent schemes have been used to provide tax assistance to

\footnotetext{
${ }^{27}$ Budget Law 2003; Decision of the COM of February 6, 2003 On the Transfer of the part of Resources received from rents of Republican Property into the Republican Budget; Decision of the COM of December 21, 2002 (with subsequent amendments) On the Approval of the Social Protection Fund Budget of the Ministry of Labor and Social Protection.
} 
economic agents, such as ex-ante and ex-post tax deferments or concessions on interest on overdue taxes. Also, the system establishing an explicit prioritization of various payments for financially weak enterprises opens scope for granting nontransparent and ad hoc tax concessions.

20. Quasi-fiscal activities are extensive and their estimated cost is not included in the budget documents nor is it presented to parliament separately nor available to the public. The public sector engages in a wide array of quasi-fiscal activities that, although well known, are not formally reported or accounted for. The NBB earns just 6.5 percent (i.e., a small fraction of the inflation rate) on its stock of claims on the government accumulated through extending direct credit to the government. Commercial banks are routinely asked to finance public sector activities at submarket interest rates that do not reflect fully the risks of the loans, and cross-subsidize its lending to priority sectors or expenditure by charging higher rates on other loans. State owned companies are required to provide or pay many welfaretype benefits and are severely restricted from shedding excess labor, effectively acting as providers of unemployment benefits. Public sector excess employment is estimated at about 10 percent of total employment. Petroleum companies operating in Belarus had been asked in the past to donate fuel to the agriculture sector. Despite recent increases in retail utility rates, the household sector continues to pay below-cost rates for heating and some other services and receives a significant hidden subsidy from the industrial sector. ${ }^{28}$ Gas supplies from Russia also involve extensive quasi-fiscal activities based on mutual concessions, including, inter alia, import prices well below world markets and preferential level of tariffs for gas transit.

\section{Information on gross public debt is partially published, but information on}

financial assets is not published. The MOF publishes information on the primary market transactions in government securities, and provides detailed information on the outstanding stock of government securities. Also, the government provides the parliament and the President with monthly information on its expenditure arrears (with a break down between central and local government). Local governments are allowed to issue their own securities and borrow directly from financial institutions outside the treasury system. Volumes and conditions of issuance are coordinated with the MOF and fiscal authorities in the regions. ${ }^{29}$ The MOF regularly uses its right to place state securities outside the auction system. Detailed

\footnotetext{
${ }^{28}$ The government has reduced the extent of cross-subsidization in the utilities and house maintenance sector over the past two years. However, there was little progress in improving cost efficiency of state-owned utility monopolists. There are real risks for a reverse cross-subsidization to emerge if the government continues to set different, economically unjustified, utility rates to different groups of customers to lower production costs of unprofitable enterprises.

${ }^{29}$ Since 2002 the MOF has been maintaining a registry of local government debt issuance, which covers all their commitments. Since 2004 a limit on the guarantees that may be issues by local governments is established as a percentage of the expenditure side of the relevant budgets.
} 
data on the transactions in government securities in the auction and private placement markets are published daily. ${ }^{30}$ Aggregate data on the foreign public debt are available for the general government sector only and are disseminated quarterly with a significant delay. ${ }^{31}$

22. Formal commitments for more regular publication of fiscal data have not been made, but the authorities have begun to release advance release date calendars, as part of their preparations to subscribe to the Fund's SDDS. Each month, the MOF compiles for internal use detailed fiscal data according to a functional classification prescribed in the Law on budgetary classification on both the republican and the consolidated general government operations. Data on economic classification are compiled monthly for the republican government and quarterly for consolidated general government. ${ }^{32}$ However, only summarized information is disseminated, often with a significant lag, on the MOF's own website and through periodic statistical publications of the MOS. ${ }^{33}$ Data on NBB and commercial bank financing of the government are compiled monthly and disseminated in aggregated form through NBB own website and publications. The MOS, NBB, and MOF have in recent months created SDDS websites and began to disseminate key SDDSprescribed data, as well as advanced data release calendars and have begun developing the needed metadata.

\section{Open Budget Preparation, Execution, and Reporting}

\section{The annual budget presentation focuses on financial compliance and the data} classification broadly meets the GFS $1986^{\mathbf{3 4}}$ standards. The Law on the Budget System and State Extrabudgetary Funds (BSL) ${ }^{35}$ defines openness as one of the main principles of the budget process. However, this principle is not fully applied in practice. The government does not present a public budget policy statement and the access to information on current fiscal performance is limited to highly aggregated data. The government approves an annual explanatory note that accompanies the budget to parliament. The explanatory note is not

\footnotetext{
${ }^{30}$ http://ncpi.gov.by/minfin/Market/Mar1.htm http://www.bcse.by/StockExchange/GCBMarket/Auctions/index.html

${ }^{31}$ Since 2004 aggregate data on external and internal debt are posted monthly on the website of the MOF http://ncpi.gov.by/minfin/SDDSr/SDDR_Eng.htm no later than 30 days after the end of the reference month.

${ }^{32}$ The MOF is planning to start compiling the economic classification of the accounts of the general government on a monthly basis in the near future.

${ }^{33}$ MOF's website (www.ncpi.gov.by/minfin/) provides summary fiscal data in the SDDS-like format.

${ }^{34}$ Government Finance Statistics manual, IMF 1986.

${ }^{35}$ Article 11.
} 
made public. The $\mathrm{BSL}^{36}$ sets a budget calendar. The budget process starts well in advance of the legal deadline and parliamentarians are involved in the early stages of budgetary discussions. However, the timetable remains compressed and the final draft budget submitted to parliament can differ dramatically from the discussed version. These could prevent the timely submission of the budget to parliament by October $1,{ }^{37}$ and limit the opportunity for in-depth parliamentary debate, as in the case of the 2003 budget. Despite the increase in budget coverage by inclusion of a number of extrabudgetary funds, it still lacks the comprehensiveness needed for sound policy analysis and clear allocation of responsibility for the collection and use of public funds. The budget classification is broadly compatible with the GFS, with the exception of some parts of the functional classification. Privatization receipts were treated as revenue prior to $2003 .^{38}$

\section{The overall balance of central government is the main indicator of the fiscal} position in the budget. Information on the general government's fiscal position is quite limited and mostly implicit. Data on the consolidated budget (including local budgets) could be found in the prebudget report (explanatory note) but the report itself is not published. The size of local budgets (oblasts and Minsk city) is significant. Their revenues account for about 45 percent of the consolidated budget revenues. Information on the broader public sector balance is not available, despite the sizable scale of quasi-fiscal activities conducted by the public sector outside the budget. Highly fragmented reporting on these activities prevents the use of a broader public sector balance as a measure of the government's fiscal position.

\section{Budget forecasts lack realism as a result of inconsistent and overly optimistic} macroeconomic assumptions. The annual macroeconomic framework is derived from the program of social and economic developments fixed for five years (2001-05) and is contained in two documents: (i) the projection of socio-economic developments produced by the MOE in collaboration with the MOF and the NBB; and (ii) the guidelines of monetary and exchange policy produced by the NBB. In preparing the annual macroeconomic framework and the budget the government is required to comply with the indicators and priorities of the five-year plan. In general, these indicators are quite optimistic, which complicates budget preparation and leads to serious deviations from the plan during implementation.

\section{A statement on medium-term fiscal policy objectives is not explicitly included in} the budget documents. The five-year plan determines a budget deficit limit of 1.5 percent of GDP as the key medium-term fiscal target, but does not specify whether this applies to the central or general government budget. The government is required to comply with this target

\footnotetext{
${ }^{36}$ Article 21 para. 4.

${ }^{37}$ The 2003 budget was presented on November 14.

${ }^{38}$ Starting 2004, privatization receipts are reflected as budget deficit financing item.
} 
in preparing the annual budget. Due to incomplete budget coverage and the treatment of privatization receipts, this deficit target does not serve as a fully reliable indicator of the fiscal stance. There is no formal rolling medium-term fiscal framework to guide budget preparation and management and to reflect the underlying economic basis and respective fiscal risks.

27. Internal control procedures are entirely focused on financial compliance, partly due to the lack of well-defined programmatic objectives. The control executed by the departments of inspection and control (some of them with regional offices) within the ministries and by the State Control Committee (SCC) is tight but its scope is narrow. The SCC acts as an internal control body, despite its administrative autonomy. The limitation to financial compliance and the absence of independent external audit undermines the effectiveness of internal control procedures.

\section{The treasury gradually expands its functions and now covers the majority of} budget revenues and expenditures at the central government budget level. The treasury system does not include the power ministries and the presidential administration, who submit their accounting reports to the treasury's main office for consolidation. Extrabudgetary operations are also, for the present, outside the treasury system. The treasury is capable of producing accurate in-year reports on central government budget outturn. The treasury accounting system allows registering commitments and verifying contracts of budget organizations and monitoring them against the fiscal targets in the approved budgets. On some occasions, the treasury is unable to finance the verified contracts. The main reason is that the actual receipts deviate significantly from the plan. Thus the unrealistic budget projections weaken the treasury system.

29. The national tax administration has the legal status of a ministry (MTL) ${ }^{39}$ and the minister is a member of the COM appointed by the president. There is a clear division of responsibility between the MOF and MTL. The MOF is responsible for the preparation of tax legislation and for revenue forecasting, and the MTL is responsible for tax collection. Both ministries coordinate their activity with respect to all tax policy issues, but the leading institution is the MOF. The tax administration reports to the government on its activity which, in its turn, reports to the parliament.

30. The legislature does not undertake a mid-year review. The government prepares and submits to the president an annual report on execution of the republican budget. The president presents the annual report to Parliament for consideration and approval. The monthly data prepared by the MOF for the implementation of the budget are accessible to Parliament for information. The monthly and quarterly aggregated reports are published on the MOF website.

\footnotetext{
${ }^{39}$ Ministry of Taxes and Levies.
} 
31. The final accounts are available within six months of the end of the fiscal year. They are not audited and certified. The report on the execution of the republican budget is presented to the legislature, and the reports on the execution of local budgets - to the respective Councils of Deputies. The reports on the execution of the extrabudgetary activities that are not explicitly included in the annual budget law are not submitted to the legislature. The report on the republican budget follows the structure of the approved budget. Therefore, it does not cover the general government fiscal position and does not provide a basis for assessing whether or not the broader fiscal targets that provide the context for the budget are achieved. Parliament reviews the report prior to the review of the draft budget for the coming fiscal year and approves it by a law. The report is published after its approval by Parliament. A similar procedure is followed with respect to the local budgets. They are also published after the approval by the Councils of Deputies. The report on the execution of the SPF is approved by the COM and is publicly available. The reports on the execution of the other extrabudgetary activities that are not included in the annual budget law are not available to the public.

\section{Assurances of Integrity}

\section{There are considerable discrepancies between budgeted and actual outturns of} main fiscal aggregates. These discrepancies are disclosed in fiscal reports, but there is little explicit analysis or explanation. In recent years, the government has tended to overestimate real economic growth and underestimate inflation, nominal wages and benefit payments. This has lead to significant increases in nominal budget revenues and expenditures during the year. Many of the expenditure increases have been based on presidential edicts that, according to Belarusian legislation, do not require prior parliamentary deliberation.

\section{Statements of accounting policy are not included in the budget and final}

accounts documents. The government accounts are produced by the treasury and are on a cash basis. The accounts are in the same format as the budget, and do not include the Innovation funds or other extrabudgetary activities. ${ }^{40}$ The power ministries (defense, interior, etc.) and the presidential administration are not covered by the treasury system, ${ }^{41}$ but submit their budget reports to the treasury head office in MOF for consolidation. The Social Protection Fund prepares and submits separate accounts to the COM. These are also on a cash basis, and give no information about future pension liabilities.

\footnotetext{
40 The MOF accounts and prepares separate statements on Innovation funds, SPF, and extrabudgetary funds of budget organizations. The draft 2005 budget stipulates that the transactions of the innovation funds will be performed through the treasury in accordance with budget legislation.

${ }^{41}$ The treasury is working to resolve certain information security issues to allow for the inclusion of these institutions in the treasury system.
} 


\section{The processes of accounts reconciliation and fiscal reporting are reasonably} effective for those financial flows that are covered by the treasury. The treasury system provides a good basis for registering expenditures payments and for reconciliation with budget appropriations and the treasury single account. These routines are less precise for the power ministries and the presidential administration. Routines for reconciliation between aggregate fiscal and monetary data are still under development. The ministry cash accounts represent one important source of discrepancies. The treasury records transfers to these accounts, not the actual payments made from them. There are also some limitations on the ability of the commercial banks to clearly identify borrowing to local governments.

35. There is no external audit body independent of the executive branch. The SCC has its mandate from Article 129 of the Constitution and from the SCC law. ${ }^{42}$ It is responsible for governmental control over budgetary compliance, the use of government property, and compliance with laws and acts regulating government property, economic, financial and fiscal relations. The SCC chairman and vice-chairman are appointed by the president. The SCC has local branches with chairmen appointed by the head of the SCC and approved by the president. The committee has significant powers to access information about budgetary activities at both the state and local levels. It also reviews the activities of the Social Protection Fund and the Innovation funds. The SCC primarily reports to the president, but the reports are shared with the COM and the parliament. They are not made publicly available.

36. Strengthening of external audit capacity is required. Currently, the SCC primarily functions as an additional layer of internal control and audit within the executive branch, by supporting and to some extent overlapping the functions of the ministerial control departments. The SCC is closely involved in the functioning of the government, for instance by taking a strong interest in whether aggregate fiscal targets are met and making proposals to this end, and does not have the independence and arms-length relationship that should characterize the work of an external auditor. The SCC controls the financial transactions of government agencies, but does not provide any certification of final accounts, neither for individual agencies nor for the government as a whole. Most of its audit staff has university degrees, but there is no requirement that they be certified accountants or auditors.

\section{The legislature does not have specific procedures to follow up on reports from}

the SCC. According to law, the SCC reports to the president. They also submit their annual reports to the parliament at the same time as the MOF submits the final accounts, but these are not made publicly available. Parliament is not given any formal role in following up on the report. This is the responsibility and prerogative of the president and the executive branch.

\footnotetext{
${ }^{42}$ Law regarding the SCC of the Republic of Belarus, January 31, 2000.
} 


\section{External scrutiny of macroeconomic models and assumptions is not actively} encouraged and is limited. Although not formalized, there are clear expectations that the views of government institutions involved in economic research and analysis are fairly consistent with official policies and projections. There are no major independent economic research institutions. Individual analysts may present alternative assessments, but there are no established processes to ensure that these views are referred to or commented on in government documents.

\section{The national statistics office is organized as a ministry, but is given some} legislative assurance of independence. According to Article 10 of the Law on Statistics, ${ }^{43}$ "illegal interference" with the work of the MOS is not allowed. This is interpreted to mean that other government bodies, such as the COM and the MOF, can be involved in the administration and finances of the ministry, but not in the actual production of statistics. The MOS is closely involved in monitoring the outcomes of government policies towards the enterprise sector. It collects detailed performance data from all enterprises in the country, so that these can be compared to the detailed government targets for the entities in the real sector. Many of the line ministries see the MOS as an information collection and dissemination organ for the government, not as an independent provider of data.

\section{IMF STAFF COMMENTARY}

40. Belarus meets the requirements of the fiscal transparency code in some important areas. There is a comprehensive legal and administrative framework for management of budget resources. The BSL contains an explicit commitment to an open and transparent budget process. Budget coverage improved considerably with the inclusion of five major extrabudgetary funds into the budget. In particular, the following were included: the agricultural goods and foodstuffs producer support fund, the employment assistance fund, the highways fund, the environmental protection fund, and the energy conservation fund. Budget execution mechanisms are quite effective, and budget execution reports are of consistent quality. The authorities are planning a number of important reforms to further improve fiscal management. The joint action plan for the currency union with Russia gives significant impetus to this process.

\section{There are several areas where current practices fall short of the fiscal}

transparency code. The functions of the executive and legislative branches and the president in the budget process are not clearly delimited, as the president routinely approves budget amendments through edicts. There is very little reporting on the public enterprise sector. The budget fails to fully disclose the activities of government agencies, by excluding the innovation funds and other extrabudgetary activities. Quasi-fiscal activities are widespread, including through the NBB, and the fiscal relationships between the central and local

\footnotetext{
${ }^{43}$ Law on State Statistics, February 17, 1997, No 18-3.
} 
government are not fully defined. The government produces considerable amounts of fiscal data and analysis, but much of this information is not made publicly available in any systematic way. Budget estimates are not based on a realistic medium-term macroeconomic framework, and do not reflect important fiscal risks. The mechanisms for external assurances of the integrity of the fiscal processes need significant strengthening.

\section{The current framework for fiscal management provides government institutions} with a number of options for nontransparent or informal financing of priority expenditures. As described in the previous paragraphs, a ministry or agency may in many cases choose to finance specific expenditures from its regular budget, from an innovation fund or from other extrabudgetary resources. The expenditures may also be covered by one of its subordinate enterprises, which may have significant financial resources, either from revenues or from borrowing. There are also examples of expenditures for certain purposes being covered by private enterprises, as a means of strengthening their relationship with government in general or a specific ministry or agency. There are persistent claims that the presidential administration maintains an extrabudgetary reserve fund. This may in part be related to the different informal financing mechanisms described above, which effectively form a virtual reserve fund.

43. The authorities should give high priority to improvements in fiscal transparency. The following paragraphs outline several immediate steps that can be taken to resolve the most critical current problems.

44. Urgent steps should be taken to establish a clear distinction between the government and public sectors and to improve reporting on public enterprise activities. The register of public enterprises and state holdings, which is maintained by the state property department in the MOE, should be made publicly available. Annual account statements for the enterprises should also be made publicly available, and the MOE should prepare consolidated financial statements for the public sector on a quarterly and annual basis. Over the next 3-4 years, accounting and auditing standards for public enterprises should be updated to ensure consistency with international standards and good practices.

45. The use of quasi-fiscal instruments in the financial sector should be abolished. This measure is already envisaged in the joint action plan for the introduction of a common currency with Russia. The practices of providing subsidized financing through the NBB and instructing private banks to provide financing to specific sectors should be discontinued, and if necessary replaced by more transparent mechanisms, such as open budget support. The current practice of direct placement of treasury securities outside the auctions system should be discontinued.

46. Quasi-fiscal activities in the nonfinancial sector should be fully disclosed in the budget and in fiscal reporting. This disclosure should include any quasi-fiscal support received from abroad (for instance through submarket prices for Russian gas imports), implicit support to enterprises and households through price controls (for instance on energy 
and supplies to agriculture), and enterprise support of government policy objectives (such as mandated contributions to various social purposes). The use of such mechanisms should be reduced significantly over the next few years, and if necessary replaced by more transparent mechanisms, such as open budget support

\section{The government should ensure that all nonconfidential fiscal information is} available to the public on a routine basis. In this area, significant improvements could be realized very quickly. A key step in the process would be to finalize the preparations for a formal subscription to SDDS. The ministries should develop procedures and guidelines to ensure that all relevant economic and fiscal data are published in full detail on ministry websites and in publications, in accordance with pre-announced publication schedules. It should be clarified that each ministry and agency has a responsibility for keeping the public informed of its activities, and that neither aggregate statistics from the MOS nor verbal references to aggregate data during press conferences are acceptable substitutes for detailed fiscal data from the responsible institution. The NBB has already taken many steps in this regard, and can serve as an example for other institutions. A key priority should be for the MOF to regularly publish detailed information about external debt and state guarantees, as well as detailed budget execution results.

48. Starting with the $\mathbf{2 0 0 4}$ budget, the realism, transparency and predictability of the budget process should be improved. Budget estimates should be based on a rolling medium-term macroeconomic framework, updated annually to give a realistic perspective of future economic developments. The budget submission from the COM to the parliament should be made publicly available at the time of its submission, to encourage public debate and scrutiny of the draft budget. The budget documents should cover all government financial activities, and provide a detailed outline of policies and programs for each sector of the government, including expected outcomes and benefits, as well as detailed technical explanations for the specific budget figures. There should be a full specification of any tax expenditures, quasi-fiscal activities, contingent liabilities and other fiscal risks. The annual budget law should give explicit limits for new state guarantees during the budget year. Key factors for long-term budget sustainability, including government pension liabilities, should be elaborated. The budget documents should also provide key data for the public enterprise sector and its interactions with the government sector. Any major in-year changes in budget allocations should be based on supplementary budget submissions to parliament. These should be made publicly available when submitted.

49. The authorities should also consider a series of additional measures to improve transparency. The measures described below are of somewhat less immediate concern than the ones in the preceding paragraphs, but will be very important to ensure the long-term transparency and stability of the fiscal system. The authorities' strengthened commitment to fiscal transparency, and the concrete improvements in budget management recommended in this section of the ROSC, should be reflected in the new budget code that currently is being developed. 
50. Budget coverage should be expanded to give a complete picture of government activities. ${ }^{44}$ One major step would be to fully include the innovation funds in the budget. Other extrabudgetary activities of the ministries and agencies, including provision of services for fees, should either be fully included in the budget on a gross basis, or organized as separate enterprises with full disclosure of their activities.

\section{Over the medium term, the fiscal relationships between central and local} governments should be clarified and put on a stable, sustainable basis. This should include a more explicit assignment of expenditures to the different levels of government. To ensure transparency and predictability, tax shares should be the same for all governments at the same level, and should not be subject to ad hoc changes. Equalization needs should be handled through a stable formula-based transfer mechanism, not by annual gap-filling negotiations.

52. The coverage of the treasury system should be expanded to all parts of government including the power ministries and the presidential administration, by 2004. This will contribute to complete and consistent fiscal reporting. The treasury should improve the quality of financial planning and cash management, and avoid resorting to ad hoc cash rationing which will lead to arrears. All payments should be based on actual cash flows, not on offsetting mechanisms. Mechanisms for reconciliation between fiscal and monetary data should be further strengthened.

53. Over the next three years, several measures should be introduced to strengthen external assurances of integrity of the budget process:

- $\quad$ The budget and the government accounts should include a detailed specification of accounting standards and policies. The MOF should begin the development of a balance sheet for the government sector, and elaborate a strategy for gradual transition toward introducing international public sector accounting standards. Line ministries should consider preparing separate annual reports.

- $\quad$ The establishment of an independent, external audit body, reporting directly to parliament and making all its findings publicly available, would be a major boost to accountability and transparency.

- State economic research institutions should be encouraged to develop and publish independent assessments of macroeconomic estimates and policies. The authorities should consider contracting external researchers and analysts, including international experts, to provide independent scrutiny of the official macroeconomic projections, and guarantee that these be made publicly available.

\footnotetext{
${ }^{44}$ Starting 2004, the SPF is included in the general government budget.
} 
- $\quad$ The MOS should be reconstituted as an independent agency, with strong legal assurances of its independent role. It should have an arms-length relationship to the executive arm of government, and should not be involved in detailed monitoring of or dissemination of information about government policies. 